\title{
Obesity expert owns up to million-dollar crime
}

Rex Dalton, San Diego

A US physiologist is facing a possible prison sentence after pleading guilty to a felony in one of the largest research misconduct cases on record.

On 17 March, through a comprehensive agreement with the US government, Eric Poehlman acknowledged falsifying 17 grant applications to the National Institutes of Health (NIH) for nearly $\$ 3$ million, and fabricating data in ten published articles.

Poehlman, 49, who could not be reached for comment, has been barred for life from receiving US grants. He faces up to five years in prison and the ten articles are being retracted.

In January, Poehlman resigned his most recent position at the University of Montreal in Canada. He has published more than 200 articles on obesity, the menopause and ageing. His eight years of misconduct up to 2000 occurred when he was a researcher at the University of Maryland in Baltimore and at the University of Vermont in Burlington, which initiated the investigation against him in 2001 .

"This is the biggest case we have ever had," says Alan Price, head investigator for the Office of Research Integrity (ORI), which monitors grants for agencies such as the NIH. The only other criminal case of research misconduct in the United States involved psychologist Stephen Bruening of the University of Pittsburgh, Pennsylvania. In 1988 he received a 60 -day sentence for providing false information about a drug study.

Authorities say Poehlman engaged in a variety of tactics to derail the investigation into his activities. All proved unsuccessful, and eventually led the US Attorney's Office in Vermont to seek the criminal conviction.

In 2001, Poehlman sued the university in federal court to prevent the ORI from being notified of possible misconduct. When he was unsuccessful, Poehlman quickly and quietly departed for Montreal, where he was given a research position endowed by the Canadian government. Montreal was not aware of the allegations until the autumn of 2003, officials say, at which point he was placed on leave.

The first questions about Poehlman's research were raised at Vermont in late 2000 by a student researcher, Walter DeNino, who observed data being altered. Last year, DeNino filed a federal false-claims suit against Poehlman for misrepresentations made to the NIH. The US government then secured $\$ 180,000$ - virtually all of Poehlman's assets - as repayment for the falsifications to the NIH. DeNino is to receive $\$ 16,000$ to cover his legal fees.

"I was shocked when I discovered Dr Poehlman's activity," says DeNino, who is currently a student at Columbia University in New York. "He and his lawyers attacked my character."

\section{No-confidence vote fails to shift Harvard president}

\section{Emily Singer, Boston}

Faculty members at Harvard University encouraged by their own audacity in passing a vote of no confidence in their president are planning to challenge him further.

Members of the university's Faculty of Arts and Sciences voted 218 to 185 against Larry Summers in a secret ballot on 15 March. Some say they will follow this by calling directly for his removal, and by censuring the Harvard Corporation, the executive board that appointed him.

Others are wondering how Summers will be able to function as president now that the largest of Harvard's faculties has approved a motion stating: "The faculty lacks confidence in the leadership of Lawrence H. Summers."

"A weakened president will not be able to lead a fund-raising campaign," suggests anthropologist Arthur Kleinman.

An immediate change in Summers' status seems unlikely, however. The Harvard Corporation continues to support him, and Summers has given no indication that he will step down. In a brief statement made after the vote, he said he would continue to work with faculty to restore a sense of trust.

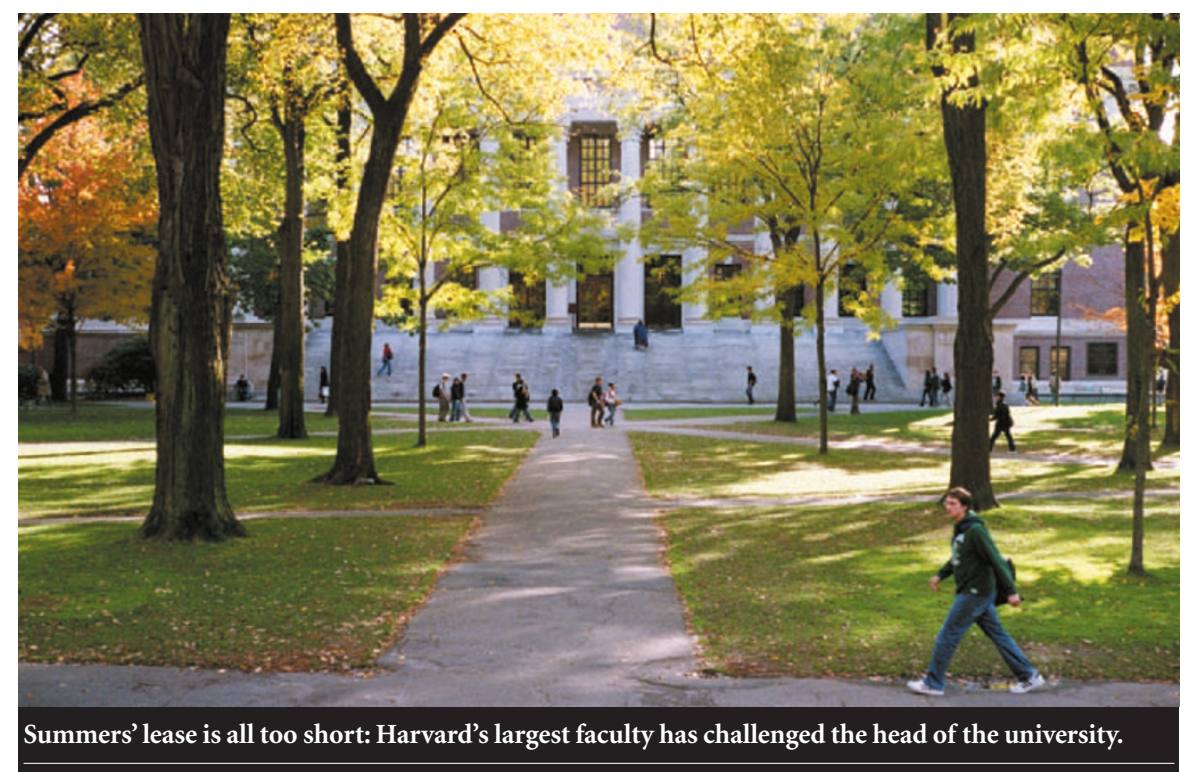

"Many of us hope a transformation will take place," says Everett Mendelsohn, a historian of science. He envisages a greater transparency in the dealings of the president - and more power for the faculty.

Lorand Matory, an anthropologist who sponsored the no-confidence motion, says he will call directly for Summers' removal at the next faculty meeting in April. There may also be a move to rebuke the corporation.

Summers came under fire after a speech on 14 January in which he suggested that differences in "intrinsic aptitude" between men and women might be a major factor behind the scarcity of senior female scientists.

Anger over the comments quickly blossomed into a broader attack on Summers' leadership style (see Nature 433, $790 ; 2005)$. Supporters and critics expressed surprise, however, at the outcome of last week's meeting, in which members also voted 253-137 for a milder rebuke.

Discontent on Harvard's campus in Cambridge, Massachusetts, is bringing other controversies to light. Last year, the Harvard School of Public Health won a fiveyear, \$107-million AIDS grant. According to a column in The Boston Globe last week, Summers and colleagues tried to take control of the project and to silence protests from its lead investigator. One senior faculty member - who declined to be identified told Nature that the crisis over Summers' tenure had encouraged those involved to start talking. "Now they are less afraid," the professor says. 